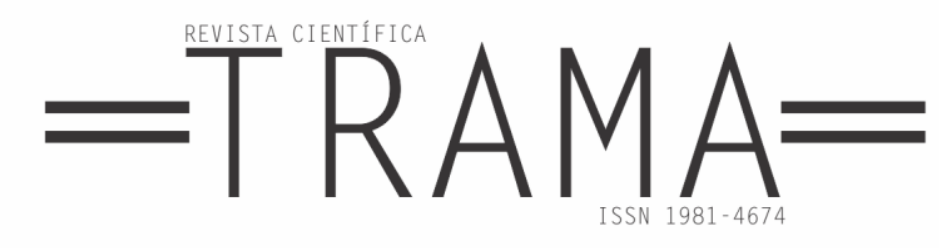

\title{
Contemplar o invisível: O CAMINHAR PELA CIDADE EM AS VOZES DE MARRAKECH DE ELIAS CANETTI
}

\author{
Gabriela Gomes de OLIVEIRA ${ }^{1}$ \\ Elcio Loureiro CORNELSEN ${ }^{2}$
}

\begin{abstract}
Resumo: $O$ presente artigo se propõe a fazer uma reflexão acerca do papel desempenhado pelos personagens invisíveis que figuram na narrativa de Elias Canetti. A cidade de Marrakech surge como o espaço mediador do caminhar do viajante que lança um olhar receptivo ao que lhe é heterogêneo, e se permite experienciar as mais várias sensações que o ato de observar o outro poderia proporcionar. Como suporte teórico principal para este texto foram escolhidos os trabalhos de Francesco Careri, Luis Alberto Brandão, Michel Foucault e Joan W. Scott.
\end{abstract}

Palavras-chave: Elias Canetti, Invisibilidade, Estranhamento.

\begin{abstract}
The present paper proposes to reflect on the role played by the invisible characters that figure in the narrative of Elias Canetti. The city of Marrakech emerges as the mediating space of the traveler's journey that takes a receptive look at what is heterogeneous, and allows himself to experience the most various sensations that the act of observing the other could provide. The main theoretical support for this text was the works of Francesco Careri, Luis Alberto Brandão, Michel Foucault and Joan W. Scott.
\end{abstract}

Keywords: Elias Canetti, Invisibility, Strangeness.

\footnotetext{
${ }^{1}$ Mestranda pelo Programa de Pós-Graduação em Estudos Literários da Faculdade de Letras da Universidade Federal de Minas Gerais - UFMG, Área de concentração: Literaturas Modernas e Contemporâneas. ${ }^{2}$ Professor Associado IV da Faculdade de Letras da UFMG - Universidade Federal de Minas Gerais, credenciado junto ao Programa de Pós-Graduação em Estudos Literários. Área de concentração: Literatura Moderna Alemã, Literatura, História e Memória Cultural, e Literatura e outras Artes e Mídias.
} 


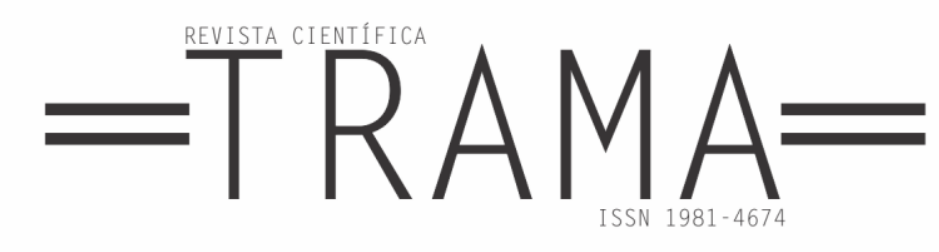

\section{Introdução}

O romancista e ensaísta Elias Canetti, ganhador do Prêmio Nobel de Literatura em 1981, representa a figura do sujeito nômade. Nascido na Bulgária, residiu na Áustria durante uma parte de sua juventude, mas, fugindo do nazismo, migrou-se para a Inglaterra em 1938 e passou a viver em Londres a partir de 1939. O alemão foi o idioma escolhido por esse escritor judeu para sua produção literária, como a que se pretende analisar neste artigo. As vozes de Marrakech, de 1954, surgiu após o autor passar alguns meses no Marrocos acompanhando amigos cineastas que lá realizavam uma filmagem. Por intermédio do caminhar pelas ruas de Marrakech e, ao mesmo tempo, do olhar de novidade lançado àquilo que está adiante, a cidade tornase, em seus escritos, palco para a descoberta de novas perspectivas com relação a costumes, pessoas e sensações.

A experiência primeira da qual Canetti permite-se participar é a da linguagem. Estar no estrangeiro, por si só, é adentrar o universo único da alteridade, no qual a heterogeneidade acentua-se ainda mais e nos propicia experiências únicas devido ao contato com o que nos é diverso. "Aquele que viaja sai de "seu" território, de um mundo que lhe é familiar, para encontrar "outros" lugares, distantes, separados de sua vivência anterior" (ORTIZ, 2000, p. 21). Canetti, um judeu que viveu integrado ao mundo ocidental, depara-se com a realidade do mundo oriental que se apresenta totalmente dessemelhante ao seu.

Durante as semanas que passei no Marrocos, não tentei aprender nem o árabe nem as línguas berberes. Não queria perder nada da força de seus gritos estranhos. Queria me expor aos sons em si mesmo, sem diluir nada por obra de um conhecimento insuficiente e artificioso. Não lera nada sobre o país. Seus costumes me eram tão desconhecidos como as suas gentes (CANETTI, 2006, p. 25).

Não compreender a língua pode ser, para muitos, algo da ordem da limitação comunicacional enquanto visitantes de uma nova localidade. Para Canetti, entretanto, os sons estranhos e incompreensíveis da língua local parecem ser a total libertação do que é convencional aos viajantes que, muitas vezes, buscam todas as informações possíveis acerca do destino antes de partir. A atitude de Canetti lhe permite o contato com o total estranhamento que a visita pode lhe causar. Isto é, ele sugere a valorização do que nos é distante, abrindo caminho para as surpresas que nos esperam ao pisar em solo estrangeiro. A incomunicabilidade por meio da oralidade não interrompe o ouvir das diversas vozes da cidade. Canetti, porém, transformou a impossibilidade do total entendimento oral em escrita que se propõe a dar a conhecer. Como afirma Foucault "ali onde não é mais possível falar, descobre-se o encanto secreto, difícil, um pouco perigoso de escrever" (2016, p. 39).

$\mathrm{O}$ ato de escrever sobre as experiências de viagem, contudo, não teria o mesmo impacto sem a presença dos personagens que constroem a narrativa. $\mathrm{O}$ encanto da escrita, como menciona Foucault, parece ter origem exatamente nos vários indivíduos que transformam não apenas as ruas de Marrakech, por onde passou Canetti, mas também o próprio olhar do estrangeiro que os fita. São esses indivíduos, assim como a própria cidade, que se tornam parte principal deste artigo que tem como objetivo refletir sobre o papel desses personagens na narrativa do autor. Quem são esses sujeitos? O que despertou em Canetti o interesse em 


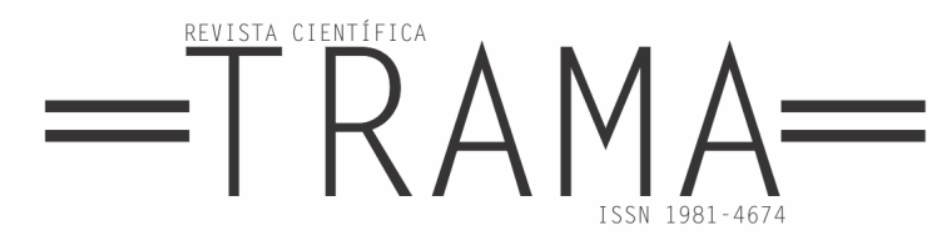

descrevê-los em sua obra? $\mathrm{O}$ ato do caminhar influenciou a forma de ver e sentir a cidade? Essas questões serão discutidas adiante tendo como amparo, principalmente, os trabalhos de Francesco Careri, Luis Alberto Brandão, Michel Foucault, Renato Ortiz e Joan Scott.

\section{Caminhar, ver e sentir}

Os suqs, grandes mercados labirínticos, aromáticos e coloridos, que possuem de tudo um pouco, não seriam talvez tão sedutores sem a presença de seus comerciantes. Ao caminhar pelos corredores dos suqs, Canetti descobriu nos mercadores uma importância tão grande quanto os produtos que vendem. $\mathrm{Na}$ verdade, o autor sugere que ambos, em meio a total diversidade do mercado, evocam uma relação de pertencimento entre si, isto é, o mercador e seus produtos encontram-se em um certo estado de unidade.

Mais do que tudo, o homem em meio a suas mercadorias está tranquilo. Sempre sentado ali, sempre por perto. Não tem lugar nem ocasião para grandes gestos. Pertence a suas mercadorias tanto quanto elas lhe pertencem. (...) Como se formassem uma família numerosíssima, eles as vigiam e as mantém em ordem (CANETTI, 2006, p. 22).

Os espaços físicos do mercado, assim como o vaivém de pessoas, ajudam a formar a imagem da dicotomia lá presente: por um lado a grande movimentação e o intenso fluxo de consumidores que dão vida ao ambiente; por outro, a serenidade do mercador cuidando de suas mercadorias. A possibilidade de presenciar a própria fabricação do produto, que logo se consumirá, parece expressar a ideia de indivisibilidade que os cerca. "Além das lojas que apenas vendem, há muitas em que se pode ver, bem à frente, como são fabricados os objetos" (CANETTI, 2006, p. 20). Aqui parece haver uma inversão de papeis: ao contrário de analisar e detalhar o produto estrangeiro, o souvenir que será presenteado a alguém querido, foca-se no fazer, na confecção mesma do item. A caminhada pelo mercado serviu, provavelmente, não apenas para contemplar as belezas marroquinas através de seus artesanatos, mas para desvendar a figura que está por trás da produção.

Presenciar a arte dos mercadores, sua maneira de agir e vivenciar o contato com outras culturas remete-nos a um termo já mencionado neste artigo: o estranhamento. É bastante comum nos surpreendermos totalmente estáticos diante de algum monumento ou de algum artista de rua quando nos encontramos em lugares distantes de nossa morada. A situação presenciada nos suqs certamente provocou uma sensação de estranhamento em Canetti, no sentido positivo que a expressão poderia denotar, isto é, o de descoberta. De acordo com Foerste e Camargo:

(...) "estranhamento" pode traduzir dois sentimentos/idéias importantes: curiosidade, $[\ldots]$ ou repúdio, contrário de singularização ou unicidade. O "estranhamento" poderá ser obtido a partir dos primeiros contatos com a obra, sensações, primeiras impressões de reconhecimento e repúdio acabam por auxiliar neste processo refletindo nas produções, dos comportamentos sociais e das falas dos sujeitos (2010, p. 260).

É proposto aqui que o sujeito que caminha por Marrakech procura experienciar tudo o que a cidade e seus habitantes podem lhe oferecer; há, de 


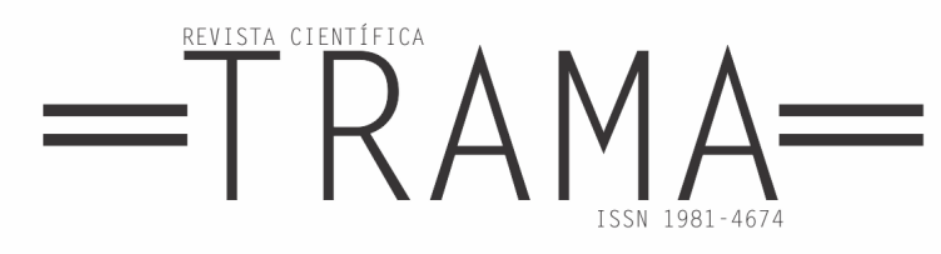

certo modo, uma imersão e um deixar-se levar em meio à multidão da cidade. Portanto, o momento de estranhamento, representado pelo mercado, sugere um sentimento de curiosidade por parte de Canetti; obtido a partir do momento em que ele observa o que lá se passa e permite $o$ contato visual com $o$ comportamento, com as falas e produções dos sujeitos que lá estão. Sendo assim, o estranhamento parece indicar a vontade de inteirar-se com o que é diferente, isto é, estranhar a novidade e ao mesmo tempo reconhecêla como algo pertinente àquela sociedade; ela faz parte do todo social e precisa-se de sensibilidade para notá-la.

Conforme afirma Careri, a prática do caminhar "tem sido reabilitada pelos poetas, pelos filósofos e pelos artistas capazes precisamente de ver aquilo que não há, para fazer brotar daí algo" (2013, p. 18). Foi a partir da perambulação realizada por Canetti dentro dos suqs que os comerciantes, por vezes notados apenas no momento da barganha, ganharam espaço no texto literário. $\mathrm{O}$ escritor viu aquilo que aparentemente não está, tornando-o algo que é, fazendo surgir sua presença. Mesmo no Marrocos, "numa sociedade que esconde tanta coisa, que veda ciosamente aos estrangeiros o interior de suas casas, o corpo e o rosto de suas mulheres e mesmo o acesso a seus templos, (...)" (CANETTI, 2006, p. 21), parece possível desvelar algo.

Os suqs descritos pelo autor não abrigam apenas aqueles que se ocupam das relações de comércio, mas também aqueles que não possuem nenhuma condição de adquirir qualquer item lá exposto. Trata-se dos cegos; quase sempre mendigos e que se postavam no centro do mercado ecoando seus pedidos em nome de Alá.

A repetição de um mesmo grito caracteriza o pedinte. Ele se impregna, todos o reconhecem, de agora em diante estará sempre ali. Ele passa a ser essa qualidade bem definida, seu grito (...). Nesse lugar, ele é o que ele grita, nem mais, nem menos, um mendigo cego (CANETTI, 2006, p. 27).

O mendigo se resume a seu grito, a seu pedido, ele é a própria repetição, a própria invisibilidade. $\mathrm{O}$ olhar do viajante que o vê ali, parado em sua posição de súplica, parece ser o olhar da empatia que não esconde, entretanto, a situação terrível que presencia. A invisibilidade que cerca este sujeito, e também outros a serem apresentados neste texto, refere-se àquela tanto de cunho social quanto textual. Não se trata aqui de fazer um levantamento dos vastos trabalhos que tenham como tema sujeitos desprivilegiados socialmente, como os mendigos de Marrakech, e que estejam representados em um texto literário. Mas, sobretudo, evidenciar sua importância nesta obra de Canetti e salientar que suas caminhadas pela cidade parecem ter despertado no autor o interesse por aqueles que compõem seu substrato social, mas, muitas vezes, não figuram como protagonistas de uma narrativa.

$\mathrm{O}$ encontro entre o observador e os observados parece ser mediado pelo espaço do mercado; local onde os mendigos transitam e que só foi descoberto pelo autor mediante seu deslocamento pelas ruas da cidade. "O espaço apresenta-se como um sujeito ativo e pulsante, um produtor autônomo de afetos e de relações" (CARERI, 2013, p. 78). O caminhar e o território da caminhada poderiam ser entendidos, nesse caso, como os propulsores que despertariam no caminhante algo da ordem da compaixão, já que a condição precária dos mendigos lhe chamou atenção. $\mathrm{O}$ fato de os mendigos estarem naquele determinado espaço poderia 


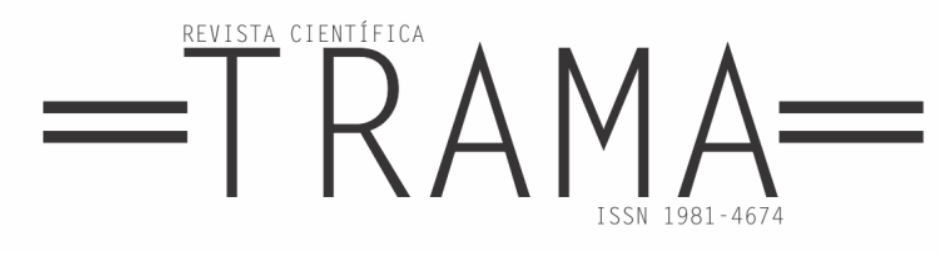

influenciar, portanto, o olhar de quem observa.

Esse olhar de alguém que caminha pela cidade assemelha-se, de certo modo, ao olhar do flâneur, de Baudelaire, que "(...) fareja rastros como quem caça, mergulha na multidão como quem se perde numa floresta, decifra pela fisionomia a história de vida de cada passante, e faz tudo isso numa peregrinação incessante pela cidade" (ROUANE, 1993 apud MENEZES, 2007, p. 20). Assim como o flâneur supracitado, Canetti mergulha em Marrakech e traz à tona momentos que lhe foram marcantes, normalmente propiciados por sujeitos anônimos. Suas andanças são feitas sempre com os olhos abertos; olhos de quem quer descobrir alguma coisa, de quem se permite sentir, cheirar, ouvir e, principalmente, entregar-se ao instante do olhar.

O flâneur "[o]lha e descreve. Personagem urbano, suas antenas sensoriais privilegiam a visão (...). Para ele a cidade é uniforme apenas na aparência, sob ela se esconde todo um mundo, realidade subterrânea ao cotidiano do homem ordinário" (ORTIZ, 2000, p. 21). O ato da flânerie, dessa forma, legitima a individualidade do sujeito. "Desenraizando-se de sua territorialidade ele pode caminhar, mover-se segundo os objetivos traçados por sua consciência individual" (ORTIZ, 2000, p. 21). Canetti, por meio de suas caminhadas atentas por Marrakech, comporta-se como um sujeito que busca por detrás do visível a "realidade subterrânea" da cidade. O sentido da visão como suporte da flânerie influenciaria, portanto, o objetivo da caminhada que consistiria em alcançar a desterritorialidade não apenas geográfica, mas, sobretudo, individual.

Diante desse suposto desejo de encontrar a face escondida da cidade, surge na narrativa a figura do marabu; homem santo para a cultura marroquina.
O personagem, que tanto chamou a atenção do autor quando este se afastou dos mendigos cegos, estava sozinho; era um velho de cabelos brancos, com as pernas encurvadas e que mastigava alguma coisa. Ao avistar aquele sujeito e observá-lo tão atenta e longamente, Canetti parece querer decifrar, pela fisionomia do marabu, suas histórias e seus mistérios. "Mastigava com zelo, como se agisse conforme prescrições. Logo se via que estava gostando muito, e, observando-o, notei sua saliva, que era abundante" (CANETTI, 2006, p. 29). O modo como o marabu mastigava instigou o observador, fazendo-o imaginar diversas coisas a seu respeito e comportar-se de maneira risível para quem o via: "Não notei que também era observado e que eu devia oferecer um espetáculo ridículo. Talvez eu estivesse boquiaberto (...)" (CANETTI, 2006, p. $31)$.

Ao deparar-se com o velho e sua cena envolvente, surge em Canetti um misto de sentimentos e desejos que o prendiam ali, na posição de quem, ao mesmo tempo, se encanta e se desencanta com o que presencia. A viagem, em si mesma, configura um distanciamento do que nos é habitual e caminhar por Marrakech sem guias turísticos, deixar-se levar pelos sons e pelos fluxos dos transeuntes parece ter sido a chave para encontros inesperados como este. Na tentativa de descobrir algo sobre aquele ser que mastigava, olhou-o tão demoradamente que, aos poucos, entendia o que se passava.

Quando terminou, lambeu os lábios algumas vezes, estendeu para frente o braço direito com os dedos esticados e lançou sua súplica de mendigo com voz feliz (...). Mordeu a moeda entre os lábios carnudos e sumiu com ela na boca (...). Tentei controlar o nojo diante daquele procedimento estranho (CANETTI, 2006, p. 30). 


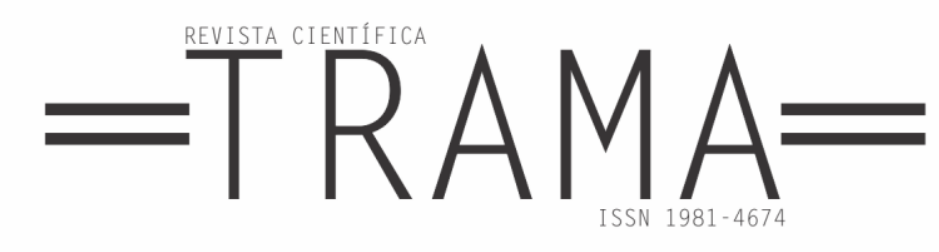

A combinação de prazer e repulsa pela moeda suja levada à boca revela $o$ mundo de sensações que cercam quem se aventura em terras estrangeiras, sobretudo com o olhar de fascínio sobre o que lhe é díspar. Além disso, o estranhamento provocado pela atitude do marabu, mastigando moedas imundas, poderia ser pensado no sentido de repúdio ("repúdio, contrário de singularização ou unicidade") que este termo indicaria. $\mathrm{O}$ repúdio seria caracterizado pelo fato de o marabu mastigar as moedas e esta ação, banal aos olhos dos marroquinos, demonstrar certa vulgaridade e repulsa a alguém que não está acostumado a ela. Por outro lado, mesmo diante da cena excêntrica, a curiosidade e até certa admiração por aquele indivíduo continuam presentes. $\mathrm{O}$ que poderia se pensar aqui é mais um envolvimento do que um afastamento com o que é heterogêneo, isto é, por mais que o gesto do mendigo lhe causasse nojo, seu olhar não desviou daquele momento, ele entregou-se ao novo. "Estava confuso e fascinado, não queria ver outra coisa além do velho" (CANETTI, 2006, p. 30).

A ação de olhar, empregada por Canetti, problematiza o fato de que quando estamos em outro local, em outras terras, tendemos a enxergar os detalhes antes despercebidos em nosso próprio país. Não se vê o que está próximo demais, o que nos é habitual. $\mathrm{O}$ interesse em visitar uma outra cultura seria entendido, dessa maneira, como o motor responsável por "fazer aparecer o que está próximo demais de nosso olhar para que possamos ver, o que está aí bem perto de nós, mas que nosso olhar atravessa para ver outra coisa" (FOUCAULT, 2016, p. 69). Em Marrakech Canetti viu aquilo que, certamente, passou despercebido em seu país de residência e que por estar lá, ao

alcance dos olhos, não ganha a devida atenção.

Este "fazer aparecer o que está próximo demais", de Foucault, parece ser possível apenas quando nós mesmos somos os desconhecidos. Se poderia pensar que o fato de estar em um lugar estranho é também tornar-se estranho para aquele local, mas esse estranhamento propiciaria o descortinamento do que está ao lado, ampliando o campo de visão e fazendo surgir uma atração pela novidade. O interesse partiria tanto dos nativos que notariam nossa "estrangeirice" quanto dos próprios viajantes que procuram registrar cada momento da nova experiência. Dessa forma, nossa visão seria atravessada pelo interesse (que pode ser positivo ou não) e não haveria o desvio do olhar.

Essa reflexão pode ser melhor compreendida no momento em que Canetti se despede silenciosamente daquele homem, notando ser ele próprio a criatura estranha no local e comentando sobre o que viu e sentiu aos companheiros de viagem: "Fui embora, mas tão impressionado que falei a respeito com todos os meus amigos. Nenhum deles o notara, e senti que duvidavam da verdade do que lhes contara (...). O marabu não significava para eles o mesmo que para mim (...)" (CANETTI, 2006, p. 32). O autor vê o que está próximo demais do olhar, mas que nem todos percebem - nem mesmo aqueles que compartilham o mesmo espaço e que se dispuseram a conhecer novas culturas. Portanto, a ideia de que estar em um determinado espaço possibilitaria a ampliação do campo de visão não se aplicaria a todos. O que não impede que as companhias do autor tenham percebido e apreciado outros lugares e situações durante o trajeto.

A ideia de visão, por sua vez, parece atrelada ao espaço onde ocorreu o encontro com a diferença. Para ver o que 


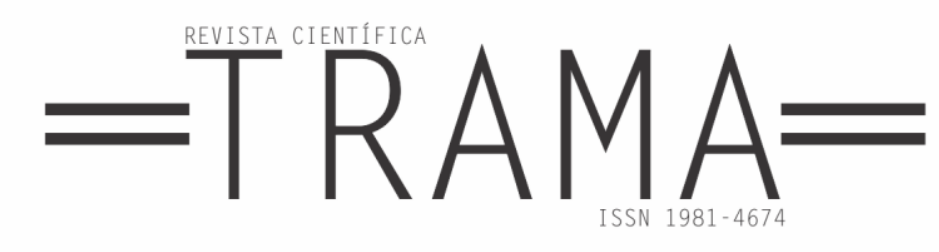

nos está próximo torna-se necessário estar no espaço onde o novo, como dito acima, se situa. A curiosidade ocasionada pelo estranhamento aliada ao percurso até aquele local onde tudo acontece, parece viabilizar o encontro entre o ser que observa e o ser observado. "Assim, o espaço se desdobra em espaço observado e espaço que torna possível a observação. Observar pode equivaler a mimetizar o registro de uma experiência perceptiva" (BRANDÃO, 2007, p. 211). O local onde estava o marabu, portanto, foi notado por Canetti (espaço observado) por meio de sua visão perceptiva e propiciou, ao mesmo tempo, a observação daquele homem santo (espaço que torna possível a observação).

A praça onde se encontrava o marabu não seria, porém, o único lugar que possibilitara o contato e o encontro com o que aponta ser diferente. Caminhando pelas ruelas da cidade, Canetti depara-se com pessoas que atraem sua atenção e tornam-se foco de sua narrativa. Há a mulher junto à grade de uma casa, com o rosto à mostra e a voz doce; os judeus que encontrara em sua visita ao Mellah, descrevendo seus olhares, trejeitos e confrontando a riqueza e a pobreza do lugar; ou ainda a visita à casa da família Dahan, tornandose próximo ao jovem Élie, conhecendo seus parentes e fazendo-lhe favores. " $\mathrm{A}$ exploração da cidade e a contínua descoberta de realidades a serem reveladas são possíveis em qualquer lugar, (...)" (CARERI, 2013, p. 77), até mesmo naqueles em que nada se espera. Para Canetti, conhecer uma casa por dentro, por exemplo, saber dos costumes e das tradições de seus moradores possuía mais valor do que visitar os palácios dos sultões marroquinos, ou prender-se às atrações turísticas mais famosas.

Por intermédio de suas andanças, entretanto, um local em especial despertou o interesse do caminhante; era a praça do bairro Mellah. "Tive a impressão de ter alcançado a verdadeira meta de minha viagem (...). Eu era essa praça em que estava. Creio que continuo a ser essa praça" (CANETTI, 2006, p. 50). Lá havia de tudo; lojas, mendigos, cozinheiros, judeus, fregueses, bazares, crianças e todas as emoções que a imensa gama de diversidade poderia ser capaz de proporcionar. Canetti sentia-se a praça, pois, possivelmente, sendo judeu oriundo da parte ocidental do globo e notando uma espécie de harmonia entre os judeus do oriente, tenha encontrado, enfim, o que buscava: a possibilidade do convívio homogêneo, simples e natural, em meio à heterogeneidade social.

Enquanto ser que caminha, que vê, que sente, que cheira, que ouve, ele era aquela praça, pois, além de integrar a cena, ainda se configura como alguém múltiplo, como uma displaced person. "Ele busca um asilo na multidão" (BENJAMIN, 2009 p. 47), se expõe e torna-se leitor da cidade ao observá-la. Canetti parece ter notado que, na verdade, pertence a essa multidão de vida agitada, que encontra sua singularidade em meio a multiplicidade. $\mathrm{O}$ refúgio na multidão mais uma vez faz referência à figura do flâneur exposto anteriormente; aquele que percorre as ruas da cidade urbana a fim de descobrir o que os olhos desatentos não notam.

O homem que se desloca no meio da multidão o faz impulsionado por sua curiosidade intelectual, ele deliberadamente toma a decisão de conhecer, de escolher os caminhos, para apreender, como uma máquina fotográfica, os pequenos detalhes da vida cotidiana (ORTIZ, 2000, p. 20).

A curiosidade do caminhante despertou a vontade de percorrer o desconhecido. A realidade daquela praça era 


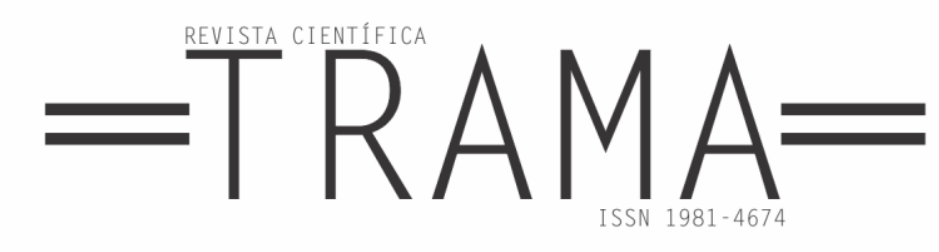

passível de ser apreendida e lida por intermédio do olhar; seja a leitura de sua arquitetura ou, ainda, dos rostos tão indistintos que transitavam de um lado para outro. A multidão que havia no recinto causava-lhe inquietação, contudo, separar-se daquele lugar e daquele momento era difícil, pois o sentimento de comunhão parece-lhe muito forte. "Assim, o caminhar revela-se um instrumento que, precisamente pela sua intrínseca característica de simultânea leitura e escrita do espaço, se presta a escutar e interagir na variabilidade desses espaços (...)" (CARERI, 2013, p. 32). O caminhar, nesse sentido, proporcionaria uma leitura também através do sentimento de ser aquela praça e do olhar que se lança sobre quem habita aquele espaço.

A leitura do espaço que tanto o tocara só foi possível por intermédio da visão receptiva, que se mostra pronta a adentrar o universo desconhecido do estrangeiro e de seus personagens. A visão, sob este aspecto, estaria ligada tanto ao "registro de uma experiência perceptiva" do viés espacial quanto ao ato de caminhar, que viabiliza a leitura desse espaço. Segundo Brandão:

A visão, entendida mais ou menos literalmente, mais ou menos próxima de um modelo perceptivo, é tida como uma faculdade espacial, baseada na relação entre dois planos: espaço visto, percebido, concebido, configurado; e espaço vidente, perceptório,conceptor, configurador (2007, p. 211).

Dessa maneira, a visão se dá a partir da relação entre o espaço real, formado, e o espaço que atribui forma àquilo que é observado. Em outras palavras, a praça do Mellah equivaleria ao espaço real, visto por Canetti. Por outro lado, a grande manifestação de pessoas e comércios daquele local representariam o espaço configurador de sentidos, ou seja, a forma do espaço real.

Sem a "alma" e a vida do espaço físico já concebido, a visão parece perder sua condição perceptiva. Caminhar pela praça repleta de ânimo foi o que aguçou o sentido da observação em Canetti, e não apenas o espaço físico que ela representa.

O percurso até a praça, que tanto o encantara, era feito diariamente. Ele retornava a ela várias vezes ao dia e também à noite, mas seu interesse, como dito acima, não se pautava estritamente em vislumbrar sua arquitetura. Esse percurso entendido como "o ato da travessia (o percurso como ação do caminhar), a linha que atravessa o espaço (o percurso como objeto arquitetônico) e o relato do espaço atravessado (o percurso como estrutura narrativa)" (CARERI, 2013, p. 31) ganha forma na obra. Aqui parece possível encontrar a ação do caminhar que percorre vários pontos de Marrakech, assim como o objeto arquitetônico a partir das descrições físicas do espaço e o relato da cidade, isto é, do espaço atravessado. $\mathrm{O}$ percurso, entretanto, deve estar associado ao sentido da visão, já que, como exposto, ela ganha forma por meio da percepção do espaço configurador. Ao observar este espaço por intermédio do percurso pela cidade, Canetti sugere uma reflexão daquilo que não é óbvio e que torna o caminhar insuficiente sem o ato de olhar o outro.

A cidade de Marrakech, espaço "concebido" e também "conceptor", é o lar daqueles que a visão muitas vezes não alcança. A invisibilidade dos viventes das cidades (para usar o termo de Derrida), em especial das grandes cidades como a Marrakesh narrada por Canetti, é algo que chama a atenção na obra.

Ao cair da tarde, fui até a grande praça no meio da cidade, e o que procurava ali não eram a vida e o colorido que eu já conhecia, 


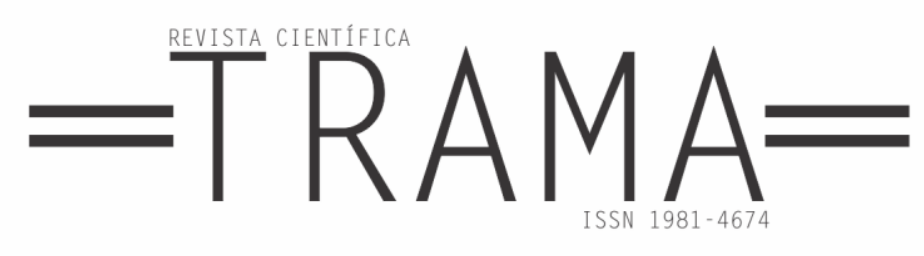

procurava uma trouxinha marrom largada no chão que era menos que uma voz, era um único som. Era um “ $\ddot{a}-\ddot{a}-\ddot{a}-\ddot{a}-\ddot{a}-\ddot{a}-\ddot{a}-\ddot{a}$ "grave,prolongado e vibrante (CANETTI, 2006, p. 109).

Essa passagem está situada no último capítulo, "O invisível", e expressa, afinal, que a busca do viajante não se alicerçava no que sempre esteve à mostra - embora toda a vibração da praça lhe causasse imensa satisfação. "Jamais vira a boca de onde vinha o " $\ddot{a}$ $\ddot{a}-\ddot{a}-\ddot{a}-\ddot{a}-\ddot{a}-\ddot{a}-\ddot{a} "$; nenhum olho, nenhuma face, nenhum pedaço do rosto (...). $\mathrm{O}$ pano marrom e sujo era puxado como um capuz por cima do corpo inteiro e escondia tudo" (CANETTI, 2006, p. 110).

Conforme Scott, "olhar é a origem do saber. Escrever é reprodução, transmissão - a comunicação do conhecimento adquirido através de experiência (visual, visceral)" (1998, p. 300). Se o ato de olhar está diretamente ligado a algo visível e a reprodução pela escrita à experiência visual e sólida, haveria lugar no texto para aqueles que normalmente não são vistos? Segundo o mesmo autor, "o visível é privilegiado; escrever é, portanto, colocado a seu serviço" (1998, p. 300). Entretanto, ao narrar seu encontro com a "trouxinha marrom largada no chão", Canetti tornou o invisível social visível para a literatura. Neste sentido, o invisível também foi privilegiado e foi acolhido pela escrita.

Em certo momento da narrativa o autor chega a nomear o "pano marrom e sujo"; chamando-lhe "criatura". Não seríamos, pois, em meio à multidão de uma grande cidade, apenas criaturas? A maioria dos personagens expostos na obra são comuns e vivem à espreita da sociedade tida como dominante. Seria interessante refletir se, do lado ocidental do globo, nós também não tendemos a agir da mesma forma, variando, às vezes, o ato da repetição diária. "Estava ali todas as noites, e toda noite meu coração parava quando ouvia o som pela primeira vez e parava de novo quando eu a via. $\mathrm{O}$ caminho que fazia para ir e vir era mais sagrado para mim que o meu próprio" (CANETTI, 2006, p. 111).

A criatura a que o autor faz alusão estava no centro da praça, desprotegida, sempre num vaivém constante de um lado para outro com as pernas arqueadas. Os movimentos desse ser eram sagrados, não porque evocava alguma prece ou se posicionava estaticamente por um longo período de tempo, mas porque ela resistia. "Eu tinha orgulho pela trouxinha, porque ela vivia" (CANETTI, 2006, p. 111). O orgulho se daria justamente porque, sendo invisível a praticamente todos os passantes daquela praça, a "trouxinha" mantinhase firme e continuava com suas preces diárias. A invisibilidade parece não incomodá-la.

A vida daquela criatura, tão neutra, simples, repetitiva, talvez miserável, despertava algo de grandioso em seu observador. Através de seu percurso até a praça e de sua abertura em experienciar o que ela lhe oferecia, parece ter sido possível alcançar o sentido da caminhada, e, por que não, de toda a viagem. Ao olhar o outro, olhar a criatura no centro da praça, haveria, por algum instante, uma vontade de desvendar o mistério daquele ser que lhe era tão próximo e distante simultaneamente. "A impotência era minha: sentia que jamais faria nada para conhecer o segredo daquela trouxinha" (CANETTI, 2006, p. 111). Nada do que fizesse seria suficiente para decifrá-la, decerto ela devesse permanecer obscura para que se integrasse de forma completa à paisagem do local: desconhecido, movediço, estranho.

$\mathrm{O}$ olhar projetado naquela oportunidade, segundo Derrida, era "completamente outro, o completamente 


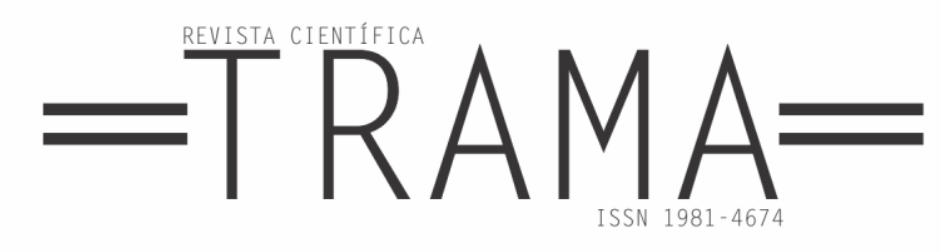

outro que é todo outro, mas que em sua proximidade insuportável, não me sinto ainda com nenhum direito e nenhum título para chamá-lo meu próximo ou ainda menos meu irmão" (2002, p. 30). Apesar de, nesse trecho, Derrida se posicionar perante a interação, por meio do olhar, entre o homem e o animal, parece não se distanciar, de certo modo, do olhar que Canetti lança sobre a "trouxinha". Ela o é completamente estranha, ela é o outro e ele também um outro que a vê. Mas ambos estão conectados por aquele instante de contemplação, e, possivelmente, por ele enxergar nela a possibilidade de vida em meio ao caos. "Mas ela vivia e, com zelo e constância sem iguais, pronunciava seu único som, pronunciava-o por horas a fio, até que fosse o único som na vasta praça, o som que sobrevivia a todos os demais" (CANETTI, 2006, p. 111). Da mesma maneira que o homem tende a ignorar os animais (em Derrida), ignora também aqueles que, em sua singularidade, tornam-se invisíveis mas sobrevivem.

\section{Considerações finais}

O sentimento de empatia refletido na imagem do ser, que por várias horas pronunciava apenas um som, parece envolvido em alguns fatores inerentes ao ato de caminhar. Saindo do convencional roteiro turístico e deparando-se com a realidade comum de Marrakech, foi possível a Canetti percorrer caminhos que o levariam a encontrar figuras muito marcantes. A praça do Mellah, por exemplo, desponta como o lugar dos diversos acontecimentos que se destacaram na obra, de modo que, se o autor não a tivesse atravessado e, como dito, desviado o olhar direcionando-o para o que é ímpar, dificilmente essa narrativa seria como efetivamente é. Dessa maneira, tanto o ato de percorrer a cidade, quanto o olhar que se lançou àquilo que se situava a frente, configurariam a válvula propulsora da obra.

Caminhar pela cidade, da forma como o fez Canetti, é também senti-la. Ouvir sua música, encantar-se com homens santos, saborear os aromas dos suqs e tornar-se íntimo, mesmo que momentaneamente, de seus moradores. Conforme Careri, "O caminhar produz lugares" (2013, p. 51), e nessa narrativa, ele parece ter produzido, além disso, relevo sobre os recantos e os seres invisíveis de Marrakech por intermédio do olhar receptivo de quem preferiu sentir a cidade, ao invés de "apenas visitá-la". Os lugares do caminhar são os lugares que o olho viu e que a mão escreveu, transformando-os em perceptíveis e até admirados por alguns. Obviamente há, ainda, muito o que se pesquisar sobre Elias Canetti e seus escritos, que, com certeza, têm muito mais a oferecer. Mas as narrativas do caminhar e do olhar certamente merecem destaque em sua produção. 


\section{$=$ TRAMA $=$}

\section{$\mathbf{R}_{\text {eferências }}$}

BENJAMIN, Walter. Passagens. Belo Horizonte: Editora UFMG; São Paulo: Imprensa Oficial do Estado de SP, 2009. 1.168 p.

BRANDÃO, Luis Alberto. Espaços Literários e suas expansões. Aletria, Belo Horizonte, v. 15, p. 207-220, jan./jun. 2007. Disponível em <http://www.periodicos.letras.ufmg.br/index.php/aletria/article/view/1397>. Acesso em: 29 ago. 2017. CANETTI, Elias. As vozes de Marrakech: anotações sobre uma viagem. Trad. Samuel Titan Jr. SP: Cosac Naify, 2006. 112 p. CARERI, Francesco. Walkscapes: o caminhar como prática estética. 1.ed. São Paulo: Ed. G. Gilli, 2013. 184 p.

DERRIDA, Jacques. O animal que logo Sou: a seguir. Trad. Fábio Landa. São Paulo: Ed. UNESP, 2002.

FOERSTE, Gerda Margit Schutz; CAMARGO, Fernanda Monteiro Barreto. Estranhamento como categoria estética em arte. Anap, Cachoeira, p. 2057-2070, 2010.
Disponível em: <http://www.anpap.org.br/anais/2010/pdf/ceav/fernanda monteiro barreto camargo.pdf $>$. Acesso em: 29 ago. 2017.

FOUCAULT, Michel. O belo perigo: conversa com Claude Bonnefoy. Trad. Fernando Scheibe. Belo Horizonte: Autêntica, 2016. MENEZES, Marcos Antônio de. Benjamin: olhares sobre o cenário urbano. História Revista, Goiânia, v. 12, n. 1, p. 15-26, jan./jun. 2007. Disponível em: <http:// https://www.revistas.ufg.br/historia/article/view/6845>. Acesso em: 28 jun. 2017. ORTIZ, Renato. Walter Benjamin e Paris individualidade e trabalho intelectual. Tempo Social, São Paulo, v. 12, p. 11-28, 2000. Disponível em: <https://www.revistas.usp.br/ts/article/view/12317/14094>.

Acesso em: 07 set. 2017

SCOTT, Joan W. A invisibilidade da experiência. Trad. Lúcia Haddad, Revisão Técnica: Marina Maluf. Projeto História, São Paulo, v. 16, p. 297-325, 1998. Disponível em: <https://revistas.pucsp.br/index.php/revph/article/view/11183>. Acesso em: 29 ago. 2017. 